\title{
A Medium for the Study of the Ecology of Human Cutaneous Diphtheroids
}

\author{
By R. F. SMITH \\ Department of Microbiology, Temple University School of Pharmacy, \\ Philadelphia, Pennsylvania 19I40, U.S.A.
}

(Accepted for publication 2 May 1969)

SUMMARY

A new medium (FTO), selective for Gram-positive bacilli from human skin, was developed, consisting of trypticase-soy, yeast-extract agar supplemented with (i) Tween $80(0.5 \%)$ to support growth of lipophilic corynebacteria. (ii) Oil Red O (0.0005\%) to distinguish lipophilic from non-lipophilic bacteria, and (iii) Furoxone (50 to $100 \mu \mathrm{g} . / \mathrm{ml}$.) to inhibit growth of Gram-negative bacilli and Gram-positive cocci. Furoxone may be used to render other media selective for more fastidious diphtheroids.

\section{INTRODUCTION}

With the exception of media for lactobacilli, there are few media that selectively isolate Gram-positive bacilli from both Gram-positive cocci and Gram-negative bacilli. Several media select for cocci or Gram-negative bacilli by inhibiting Grampositive bacilli. Selective media continue to play a vital role in studying the ecology of bacteria indigenous to man. Ritz (1966) developed a polymyxin + gluconate medium deficient in organic nitrogen to isolate oral Nocardia, Corynebacterium and Bacterionema species. Staphylococci and micrococci are regularly found in the oral cavity (Pike, I962) but their numbers are low and they can be excluded from oral bacterial enumerations by a few tenfold dilutions (Handelman \& Mills, 1965).

On human skin, the predominant autochthonous bacteria are the Gram-positive cocci and corynebacteria (Sarkany \& Gaylarde, I968). Despite much research dealing with the sterilizing properties of skin and its vulnerability to infection, surprisingly little attention has been given to studying the ecology of the resident cutaneous bacteria (Marples, 1965). There appear to be many more lipophilic corynebacteria on human skin than was once thought (Smith, 1969). Information on the distribution and types of these bacilli relative to cocci is lacking as is knowledge of ecological factors that may regulate these two major groups of skin bacteria.

As a preliminary step in these studies, a medium was sought to select cutaneous Gram-positive bacilli but inhibit the often abundant Gram-positive cocci; its development and evaluation is reported here.

\section{METHODS}

Organisms and cultures. The sources of the reference strains used in this study were previously reported (Smith, 1969). This group included the following: American Type Culture Collection (ATCC)-Listeria monocytogenes ATCC 15313, Kurthia zopfii 
ATCC 6900, Microbacterium lacticum ATCC 8180, Brevibacterium linens ATCC9172, Mima polymorpha ATCC I429I, Propionibacterium acnes ATCC I 1828, Corynebacterium parvum ATCCI1829, C. striatum ATCC6940, C. minutissimum ATCC23347, C. xerosis ATCC 373 and 7064, C. bovis ATCC7715;C. xerosis-29 (Midwest Culture Service), C. bovis-65 (National Institute for Research in Dairying, England, and C. diphtheriae COBE. Non-designated strains were part of the departmental collection. In addition, the following anaerobic Corynebacterium species were kindly supplied by C. H. Zierdt, Clinical Pathology Dept., Clinical Center, National Institutes of Health, Bethesda, Md., U.S.A.: C. granulosum 3024B, C. diphtheroides 2764, C. liquefaciens 3044B, $C$. pyogenes 637 B and C. lymphophilium PRÉvor. Gram-positive cocci isolated from human skin were identified by the methods of Baird-Parker (1962). Diphtheroids were identified by the methods of Smith (1969). Most aerobic bacteria were maintained on Todd-Hewitt slopes (Difco). Lipophilic corynebacteria (LC) were stored on the same medium supplemented with $0.1 \%$ Tween 80 . Anaerobes were maintained in thioglycollate medium (Difco) and experiments with the latter group were conducted in Brewer jars. All tests were made at $35^{\circ}$.

Antibiotic sensitivity tests. Sensi-discs (BBL, Baltimore Biological Laboratory, Baltimore, Md., U.S.A.) were used for screening facultative cultures. Strains were grown 24 or $48 \mathrm{hr}$ in trypticase-soy broth (TS) without glucose supplemented with $0.1 \%$ Tween 80 . Cultures were diluted $\mathrm{I} / \mathrm{IO}$ in sterile broth and $0 . \mathrm{I} \mathrm{ml}$. of the dilution was spread on Mueller-Hinton agar (Difco) containing $0.1 \%$ Tween 80 . After the inoculum dried, antibiotic discs were placed on the plates and incubated I to 3 days. Strains were considered inhibited when sharp well-defined zones at least $2 \mathrm{~mm}$. in width were observed. Anaerobes were tested on $5 \%(\mathrm{v} / \mathrm{v})$ whole unwashed human blood agar. In other experiments, certain antibiotic compounds were tested in TSTween 80 broth using conventional twofold dilution methods. Growth was measured turbidimetrically.

Skin enumeration technique. Skin swabbings were made by the method of Smith \& Willett (1968) and samples were diluted in tenfold amounts. One-tenth ml. amounts of certain dilutions were spread on various media and incubated aerobically I to 5 days. Colony counts were expressed as colonies per sample derived from elution of the swabs. Total counts were made using TS agar containing $0.25 \%$ glucose, $0.2 \%$ Tween 80 and $0.1 \%$ yeast extract. Gram-positive cocci were isolated on mannitol salt agar (BBL), coliform bacilli and Mima species were isolated on Herellea agar (Difco) and diphtheroids on the media described below.

Special test media. For reasons presented in the results, the following media were prepared and studied. The TS agar without glucose was supplemented with $0.1 \%$ yeast extract, 50 to $100 \mu \mathrm{g}$. $/ \mathrm{ml}$. Furoxone ( $N$-[5-nitro-2-furfurylidene]-3-amino-2oxazolidone, courtesy of H. R. Bennett, Norwich Pharmacal Co., Norwich, N.Y., U.S.A.), $0.5 \%$ Tween 80 and $0.0005 \%$ Oil Red O (Fisher Scientific Co., King of Prussia, Pa., U.S.A.). Oil Red $\mathrm{O}$ was used in the concentration recommended by Del Giudice \& Carski (1968). Furoxone and Oil Red O were each dissolved in acetone. No other form of sterilization was required. These two compounds were added to the basal medium after sterilization. The medium containing Furoxone, Tween 80 and Oil Red $\mathrm{O}$ is referred to as FTO agar, medium without Furoxone as TO and without Oil Red O as FT. Each medium had a final pH of $7 \cdot 0$. The medium of Ritz (I966) was evaluated and compared to FTO agar in certain experiments. The composition of 
Ritz agar was (g./l.): potassium gluconate, $10 \cdot 0 ; \mathrm{KNO}_{3}, 10 \cdot 0 ; \mathrm{K}_{2} \mathrm{HPO}_{4}, \mathrm{x} \cdot 0 ; \mathrm{NaCl}$, $0.5 ; \mathrm{MgSO}_{4} .7 \mathrm{H}_{2} \mathrm{O}, 0.8 ; \mathrm{MnCl}_{2} .4 \mathrm{H}_{2} \mathrm{O}, 0.14 ; \mathrm{FeSO}_{4} .7 \mathrm{H}_{2} \mathrm{O}$, 0.04; yeast extract, 0.5; Noble agar (Difco), 20. After sterilization, polymyxin B sulphate, I $75 \mu \mathrm{g}$. (I3 units)/ ml. was added; final $\mathrm{pH} 7 \cdot 2$. In testing this medium, $0.1 \%$ Tween 80 was sometimes added or the yeast extract or polymyxin were sometimes omitted.

Table I. Sensitivity of Gram-positive cocci and bacilli to nitrofuran compounds

\begin{tabular}{|c|c|c|c|c|c|}
\hline \multirow[b]{2}{*}{ Organisms } & \multirow{2}{*}{$\begin{array}{l}\text { No. of } \\
\text { strains } \\
\text { tested }\end{array}$} & \multicolumn{4}{|c|}{ Compound-Ioo ( $\mu$ g. per disc) } \\
\hline & & Furacin & Furadantin & Furoxone & Furamazone \\
\hline \multirow{2}{*}{\multicolumn{6}{|c|}{$\begin{array}{l}\text { Staphylococci } \\
\text { Subgroup }\end{array}$}} \\
\hline & & & & & \\
\hline I & 4 & 0 & 0 & 0 & 0 \\
\hline II & 5 & 0 & 0 & 0 & 0 \\
\hline IV & 3 & 0 & 0 & 0 & 0 \\
\hline VI & 4 & 0 & 0 & 0 & o \\
\hline \multicolumn{6}{|l|}{$\begin{array}{l}\text { Micrococci } \\
\text { Subgroup }\end{array}$} \\
\hline I & 2 & 0 & 0 & 0 & 0 \\
\hline 3 & 2 & 0 & 0 & 0 & 0 \\
\hline \multicolumn{6}{|c|}{ Lipophilic corynebacteria } \\
\hline Group & & & & & \\
\hline I & $\mathbf{I}$ & 0 & 0 & I & $\mathbf{I}$ \\
\hline II & 8 & 0 & 0 & 0 & 0 \\
\hline III & 9 & 0 & 0 & 0 & 0 \\
\hline IV & 12 & 0 & I & o & I \\
\hline IV $a$ & 12 & $6^{*}$ & 8 & II & I \\
\hline V & 9 & 0 & 0 & 0 & 0 \\
\hline VI & 8 & I & 3 & 4 & I \\
\hline VII & 7 & I & 3 & 5 & I \\
\hline \multicolumn{6}{|l|}{ Reference bacilli } \\
\hline K. zopfii & I & - & - & + & - \\
\hline M. lacticum & I & - & + & + & - \\
\hline B. linens & I & + & + & + & + \\
\hline C. striatum & I & - & - & + & - \\
\hline C. minutissimum & I & - & - & + & - \\
\hline C. bovis & 2 & - & + & + & - \\
\hline C. diphtheriae & I & - & - & + & - \\
\hline C. xerosis & 3 & - & 2 & + & - \\
\hline
\end{tabular}

\section{RESULTS}

Twenty Gram-positive cocci and $66 \mathrm{LC}$ strains previously isolated from human skin together with I I reference bacilli were compared for their sensitivity to 16 antibacterial drugs. Most of the cocci were resistant to triple sulphonamide, sulphathiazole and gantrisin but the bacilli were inhibited. Neomycin, penicillin, aureomycin, chloramphenicol, streptomycin, erythromycin, tetracycline and bacitracin were inhibitory to $96 \%$ of the tested strains. Some exceptions were three penicillin-resistant staphylococci and Brevibacterium linens, which was resistant to penicillin, triple sulphonamide and bacitracin. Approximately one-half of the cocci and bacilli showed a partial resistance to polymyxin. The cocci were uniformly inhibited by four nitrofurans but many bacilli were resistant to one or more of these compounds (Table $\mathrm{I}$ ). The strains initially 
tested and others were examined for their sensitivity to furoxone in broth culture. Cocci were inhibited by I to Io $\mu \mathrm{g}$. furoxone $/ \mathrm{ml}$. but all of the bacilli including those inhibited by furoxone sensi-discs were resistant to $50 \mu \mathrm{g}$. furoxone $/ \mathrm{ml}$. in broth.

Anaerobic corynebacteria grew poorly in the test broth but when tested by the disc method on blood plates were also resistant to $50 \mu \mathrm{g}$. furoxone. $/ \mathrm{ml}$. Mima polymorpha and one strain each of Klebsiella (Aerobacter) aerogenes and Escherichia coli were inhibited by $25 \mu \mathrm{g} . / \mathrm{ml}$. furoxone in broth culture.

Table 2. Selectivity of FT agar in the isolation of cutaneous bacteria

\begin{tabular}{|c|c|c|c|c|c|}
\hline \multirow{2}{*}{$\begin{array}{l}\text { Cutaneous } \\
\text { site } \\
\text { sampled }\end{array}$} & \multirow{2}{*}{$\begin{array}{l}\text { No. of } \\
\text { subjects } \\
\text { sampled }\end{array}$} & \multicolumn{4}{|c|}{ Growth on media } \\
\hline & & Blood* & $\begin{array}{c}\text { Mannitol } \\
\text { salt* }\end{array}$ & Herellea & FT \\
\hline Scalp & IO & + & + & 0 & I \\
\hline Face & 6 & + & + & I & 0 \\
\hline Nasal & 6 & + & + & 0 & 5 \\
\hline Ear canal & 6 & + & + & 0 & 3 \\
\hline Forearm & 6 & + & $5^{*}$ & $\mathbf{I}$ & 0 \\
\hline Interdigital & 6 & + & + & 0 & $\mathbf{I}$ \\
\hline Groin & $\mathbf{I}$ & + & + & 0 & I \\
\hline Axilla & I & + & + & 0 & 0 \\
\hline
\end{tabular}

Swabbings from each area were washed in $5 \mathrm{ml}$. buffer and o.I $\mathrm{ml}$. of the washing was spread on each medium. The FT agar contained $100 \mu \mathrm{g}$. $/ \mathrm{ml}$. furoxone. All plates were incubated aerobically for 5 days. Plates containing 30 to 300 colonies were scored as positive.

$*+=$ all samples positive.

$\dagger$ Number of plates positive out of total tested.

Furoxone was used in FT medium for further studies as a selective medium for Gram-positive bacilli. Skin swabbings from eight sites of 37 males and 5 females were inoculated on FT agar and other media (Table 2). All 42 samples produced heavy abundant growth on blood agar and mannitol salt agar. Compared with these media, FT agar was selective permitting growth from only I I samples. A total of I44 colonies were randomly taken from FT agar and I3I were Gram-positive bacilli. The other 13 colonies, considered to be contaminants, originated from five subjects and consisted of either yeasts or yellow pigmented tetrad-forming cocci. Both types were recognized by their colonial morphology.

Since many cutaneous bacilli or diphtheroids are lipophilic, Oil Red O, a fat dye was added to the furoxone and Tween 80 agar (FTO). On FTO agar, strains of Corynebacterium striatum and C. xerosis produced slight pink hues partly because of their production of tan-beige pigments, partly because of some dye absorption. One strain of Bacillus subtilis was inhibited on FTO agar for $36 \mathrm{hr}$ but eventually grew, producing a colourless colony. None of the anaerobic corynebacteria produced a positive dye reaction on FTO medium during 12 days incubation. When furoxone was omitted from the agar (TO type), 20 staphylococci and micrococci grew but did not absorb the dye to the extent that the LC strains did. Cutaneous LC strains and strains of $C$. bovis produced uniformly pink or red colonies, indicating uptake or concentration of lipid materials in the colonies. Colonies of 6 enteric Gram-negative bacilli of the coliform type also produced colourless colonies on TO agar.

Skin swabbings were taken from six sites (ear canal, face, nares, scalp, toeweb and groin) of six subjects and inoculated on TO and FTO agars. Only pink or dye-positive 
colonies were taken from the TO media and compared to pink or colourless colonies isolated on FTO agar (Table 3). Sixty-one isolates were identified and represented seven of eight provisional groups of LC strains. There were no contaminants found on either medium.
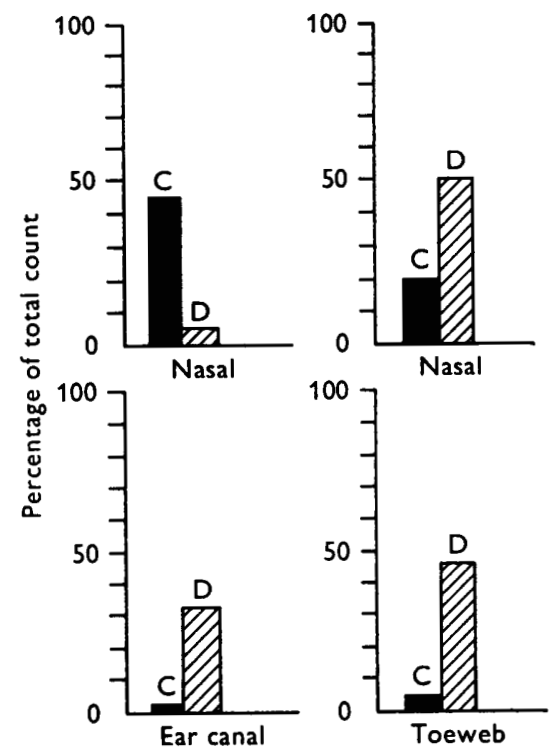

Fig. I. Frequency and distribution of Gram-positive bacilli relative to Gram-positive cocci on human skin. Samples were taken from four individuals. Dark areas, $\mathbf{C}=$ cocci; crosshatched areas, $\mathrm{D}=$ bacilli or diphtheroids. The latter were counted on FTO agar with $50 \mu \mathrm{g} . / \mathrm{ml}$. furoxone.

Table 3. Isolation and identification of cutaneous lipophilic corynebacteria on TO and FTO media

$\begin{array}{ccc}\text { LC group } & \overbrace{\text { identified }}^{\text {No. of isolates }} \\ \text { I } & \text { TO agar } & \text { FTO agar } \\ \text { II } & \text { I } & 0 \\ \text { III } & 1 & 0 \\ \text { IV } & 7 & 1 \\ \text { IV } a & 4 & 2 \\ \text { V } & 5 & 2 \text { I } \\ \text { VI } & \text { I } & 0 \\ \text { VII } & 4 & \text { I }\end{array}$

From TO agar only those colonies absorbing Oil Red O were isolated. Isolates from FTO plates were randomly selected regardless of extent of dye absorption.

Skin bacteria were counted using FTO agar for diphtheroids (Fig. I). Total counts from four samples ranged from 320,000 to $3,000,000$ bacteria per specimen; FTO agar demonstrated the relative numbers of diphtheroids present at the various sites compared to the Gram-positive cocci. Nasal samples from two individuals revealed inverse relationships in the numbers of diphtheroids and cocci present.

In experiments with Ritz agar, Tween 80 was a required supplement to support 
growth of the LC strains. Kurthia zopfii, Brevibacterium linens, Klebsiella aerogenes and Mima polymorpha grew on the medium without yeast extract but were inhibited by polymyxin. Yeast extract was essential for the growth of the remaining organisms (Table 4). Some reference bacilli and LC strains grew poorly on Ritz complete medium containing Tween 80 and all of the strains recorded as growing adequately developed more rapidly on control plates. Skin swabbings of nasal, groin and anal areas were streaked on Ritz's complete medium and incubated aerobically for 5 days. Gram-positive cocci and bacilli were present equally in randomly selected colonies.

Table 4. Growth of various bacteria on Ritz agar and its modifications

\begin{tabular}{|c|c|c|c|c|}
\hline \multirow[b]{2}{*}{ Organisms tested } & \multirow{2}{*}{$\begin{array}{c}\text { Complete } \\
\text { medium }\end{array}$} & \multirow{2}{*}{$\begin{array}{l}\text { With yeast } \\
\text { extract minus } \\
\text { polymyxin }\end{array}$} & \multicolumn{2}{|c|}{ Without yeast extract } \\
\hline & & & polymyxin + & polymyxin - \\
\hline \multicolumn{5}{|l|}{ Cocci } \\
\hline I S & + & + & - & - \\
\hline II $\mathrm{S}$ & + & + & - & - \\
\hline IV $\mathrm{S}$ & + & + & - & - \\
\hline VI S & $\mathbf{W}$ & $\mathbf{W}$ & - & - \\
\hline I $\mathbf{M}$ & + & + & - & - \\
\hline $3 \mathrm{M}$ & + & + & - & - \\
\hline \multicolumn{5}{|l|}{ LC strains } \\
\hline II-I 43 & + & + & - & - \\
\hline III -65 & + & + & - & - \\
\hline IV -33 & $\mathbf{W}$ & $\mathbf{w}$ & - & - \\
\hline $1 V a-171$ & $\mathbf{W}$ & W & - & - \\
\hline IVa-II2 & + & + & - & - \\
\hline $\mathrm{V}-27$ & + & + & - & - \\
\hline VI-3I & W & $\mathbf{w}$ & - & - \\
\hline VII-140 & + & + & - & - \\
\hline \multicolumn{5}{|l|}{ Reference strains } \\
\hline C. minutissimum & W & W & - & - \\
\hline L. monocytogenes & W & W & - & - \\
\hline$K$. zopfii & - & + & - & + \\
\hline B. linens & - & + & - & + \\
\hline C. xerosis & + & + & - & - \\
\hline C. bovis & + & + & - & - \\
\hline C. striatum & + & + & - & - \\
\hline M. polymorpha & - & + & - & + \\
\hline$K$. aerogenes & - & + & - & + \\
\hline
\end{tabular}

All media contained $0.1 \%$ Tween 80 to support growth of the LC strains. Cultures were incubated for 5 days and compared to growth on TS-Tween agar. +, Growth; -, no growth; W, weak or poor growth.

\section{DISCUSSION}

There are probably no infallibly selective media. Ritz's agar has some use in isolating cutaneous diphtheroids but certain Gram-positive bacilli did not grow on the complete medium containing polymyxin. Among strains that did grow, none developed as rapidly on Ritz agar as they did on peptone media. In addition, stock cultures of Gram-positive cocci grew on Ritz agar and were identified on the medium from skin swabbings. This would make the medium unsuitable for presumptive separation and counting of cutaneous diphtheroids. The polymyxin concentration can not be increased because bacilli rather than cocci would then be inhibited (Finegold \& Sweeney, I96I: Hobbs, Kendall \& Gilbert, 1968). 
Considerable variation in bacterial counts from skin occur because of different sampling techniques and the exact layer or area of skin that is examined (Updegraff, 1964). The FTO medium appears to be selective for Gram-positive bacilli of human skin and appears suitable for counting them. This can be accomplished without timeconsuming subcultures and Gram staining from colonies for morphological separation from cocci. In this study it was repeatedly observed that some diphtheroids, because of their small size and rounded ends, are often difficult to distinguish microscopically from cocci. No Gram-negative bacteria were detected on FTO agar during its evaluation, which included samples from more than 50 individuals.

The inverse relationship in the numbers of cocci and diphtheroids observed from two different nasal samples does not appear to be a random event. Studies of the nasal flora of 12 subjects has indicated that the inverse relationships in most subjects remain constant over a period of several months (unpublished data) and a possible ecological basis for these data is now being studied.

Many selective media are effective only within a limited incubation period. After 5 days incubation, the contaminants found on FTO agar were the yellow sarcina-like cocci and yeasts. These groups were infrequently found, but when present, could be distinguished by colonial morphology.

FTO agar is relatively simple to prepare and can be modified in several ways. If Oil Red $\mathrm{O}$ is omitted, lipophilic bacteria cannot be directly counted. If furoxone is omitted, all types of common skin bacteria will grow but the lipophilic types can be differentiated by their dye absorption. Furoxone may also be incorporated into other media that will support the growth of more fastidious diphtheroids. Preliminary studies indicate that FTO agar ( $50 \mu \mathrm{g}$. furoxone $/ \mathrm{ml}$.) is effective in isolating Gram-positive bacilli and filamentous forms from the oral cavity.

\section{REFERENCES}

BAIRD-PARKER, A. C. (1962). The occurrence and enumeration, according to a new classification, of micrococci and staphylococci in bacon and on human and pig skin. J. gen. Microbiol. 25, 352.

Del Giudice, R. A. \& CARSki, T. R. (1968). Characterization of a new Mycoplasma species of human origin. Bact. Proc. p, 67.

Finegold, S. M. \& SwEENEY, E. E. (I961). New selective and differential medium for coagulasepositive staphylococci allowing rapid growth and strain differentiation. J. Bact. 8r, 636 .

Handelman, S. L. \& Mils, J. R. (1965). Enumeration of selected salivary bacterial groups. J. dent. Res. 44, 1343.

HobBs, B. C., Kendall, M. \& GLBERT, R. J. (I968). Uso of phenolphthalein diphosphate agar with polymyxin as a selective medium for the isolation and enumeration of coagulase-positive staphylococci from foods. Appl. Microbiol. x6, 535 .

MARPLeS, M. S. (1965). The Ecology of the Human Skin. Springfield, Ill.: C. C. Thomas.

PIKE, E. B. (1962). The classification of staphylococci and micrococci from the human mouth. J. appl. Bact. $25,448$.

RrTz, H. L. (1966). Selective medium for oral nocardia. J. dent. Res. 45, 41 I.

Sarkany, I. \& Gaylarde, C. C. (I968). Bacterial colonisation of the skin of the newborn. J. Path. Bact. 95, 115.

Sмrт, R. F. (1969). Characterization of human cutaneous lipophilic diphtheroids. J. gen. Microbiol. $55,433$.

Smith, R. F. \& WILleTt, N. P. (1968). Lipolytic activity of human cutaneous bacteria. J. gen. Microbiol. 52, 441 .

UPDEGRAFF, D. M. (1964). A cultural method of quantitatively studying the microorganisms in the skin. J. invest. Derm. 43, 129. 